\title{
Study of Building Mass Forms in Jardin Cihampelas Apartment
}

\author{
Andiyan $^{1}$, Wima Alkad Albadira ${ }^{2}$ \\ e-mail: andiyanarch@gmail.com ${ }^{1}$,wima.albadira@gmail.com ${ }^{2}$ \\ Architecture Study Program, Faculty of Science and Engineering, Universitas Faletehan, Bandung ${ }^{1,2}$
}

\section{Abstrak}

Jalan Cihampelas Bandung merupakan salah satu daerah tujuan wisata utama di Kota Bandung, selain itu Cihampelas juga merupakan area pemukiman dengan kepadatan penduduk yang tinggi. Jalan Cihampelas memiliki banyak tempat hunian salah satunya Apartement Jardin Cihampelas, Apartemen Jardin Cihampelas merupakan bangunan yang Terdiri dari 4 tower bangunan yaitu tower A, B, C, dan D. Masing - masing tower memiliki 23 lantai dan bentuk masa U, Tower A - B dan C - D terletak berdekatan saling berhadapan pada bagian dalam massa berbentuk " $U$ " yang mengelilingi kolam renang. Pendekatan yang digunakan adalah Geometri dan bentuk dasar, Geometri dan bentuk dasar menunjukkan bahwa arsitektur itu adalah ekspresi dari manusia, dan merupakan prinsip dasar yang selalu hadir dari suatu karya arsitektur.Tujuan penelitian ini untuk mempelajari kaitan antara bentuk geometri yang mempengaruhi massa bangunan apartemen Jardin Cihampelas. Metode yang digunakan adalah metode kualitatif deskriptif dengan cara survey lapangan, penelitian yang dikaji adalah bentuk massa bangunan pada bentuk geometri. Variabel penelitian yang akan di bahas antara lain pengaruh bentuk dasar, kesatuan, proporsi, keseimbangan, irama dan titik berat. Penelitian ini diharapkan mendapat hasil yang bermanfaat dari kajian bentuk massa bangunan pada apartemen jardin cihampelas dengan tipologi hunian bangunan tinggi dengan bentuk geometris dalam pengolahan ruang pada bangunan.

Kata Kunci : Cihampelas, Apartemen, geometri , bentuk dasar

\section{Abstract}

Cihampelas Street Bandung is one of the main tourist destinations in Bandung; besides that, Cihampelas is also a residential area with a high population density. Jalan Cihampelas has many residential places, one of which is the Jardin Cihampelas Apartment. The Jardin Cihampelas Apartment is a building consisting of 4 building towers, namely towers $A, B, C$, and D. Each tower has 23 floors, and a $U$ shape, Tower A - B and C - D are located close to each other on the inside of the " $U$ " shaped mass surrounding the swimming pool. The approach used is geometry, and basic shapes, geometry and basic shapes show that architecture is an expression of humans and is a basic principle always present from a work of architecture. This research aims to study the relationship between geometric shapes that affect the Jardin Cihampelas apartment building mass. The method used is a descriptive qualitative method using field surveys; the research study is the shape of the building mass in geometric shapes. The research variables that will be discussed include basic form, unity, proportion, balance, rhythm and emphasis. This research is expected to get useful results from studying the mass shape of the building in the Jardin Cihampelas apartment 
with the residential typology of tall buildings with geometric shapes in the processing of space in structures.

Keywords: Cihampelas, Apartments, geometry, basic shapes

\section{Introduction}

According to (Ernst, 2002) Apartments are "residential buildings that are separated horizontally and vertically so that they are available for independent housing and include low-rise or high-rise buildings, equipped with various facilities by specified standards". Placement of a residential building design such as an apartment is usually built in a strategic location close to public facilities to increase the selling value of those interested in residential premises. Apartments have a similar function to flats, distinguishing them only from the quality of the building materials and shapes(Putri, 2015).

In architecture, every building designed cannot be separated from the geometric shape, which is the basic form in the design of a building. The geometry and basic conditions of buildings are interesting because geometry and basic shapes have a big role in designing or designing from the side of the building shape and the outside of the building. Of course, the types of services provided to the community will also be adjusted(Fokaides et al., 2020). The city of Bandung is the largest metropolitan city in West Java Province and is the capital of the province. The city is located $140 \mathrm{~km}$ southeast of Jakarta and is the third-largest city in Indonesia after Jakarta and Surabaya. Based on data from the Central Statistics Agency (BPS) of Bandung City, the population of Bandung is currently proliferating(Andiyan \& Nurjaman, 2021).

The object taken for this research is the Jardin Cihampelas Apartment, located in Bandung, which is adjacent to a shopping centre and tourist centre. Jardin Cihampelas Apartment consists of 4 building towers, namely towers $A, B, C$, and $D$. Each tower has 23 floors, and a $U$ shape, Towers $A$ - $B$ and $C-D$ are located close to each other on the inside of the mass and shaped " $U$ " around the swimming pool. Research on geometry and basic shapes in the Jardin Cihampelas Apartment building aims to determine how geometric shapes and basic shapes influence mass compositions in an apartment or residential building for young architecture. So the problem raised in this study is how to apply geometry and basic shapes to the shape of the Jardin Cihampelas Apartment building. Therefore, it is necessary to design a simple rental apartment or row house that can support the community's needs in terms of social and living comfort. Infrastructure development is one of the important and vital aspects to accelerate the national development process, especially in Java, which greatly affects economic and population mobility, especially in 2025 when the population will reach around 151 million people(Andiyan, Rachmat, 2021).

\section{Theoretical basis}

\section{Form}

According to (Fracis D K Ching, 2008), form is an inclusive term with several meanings. It can refer to an external, recognizable appearance, such as a chair or the human body sitting on it. It can also indirectly refer to a special condition in which something acts or manifests itself, such as 
when we talk about water in the form of ice or vapour. In art and design, we often use the term to symbolize the typical structure of a car's way of structuring and coordinating elements and parts parts in composition to produce an image that is logical and consistent(Cardellicchio, 2018).

Within the scope of this study, the form offers reference to both internal and external structures and the principles that give unity to the whole. Whereas form often implies a three-dimensional sense of mass or volume, then basic forms refer more specifically to the very important aspects of form which control the appearance of the relative configuration or disposition of lines or contours that define the boundaries of a figure or form(Hashimah \& Ismail, 2015). This study aims to develop knowledge of how the effect of revitalization on buildings in cultural heritage areas, especially the Sarinah Braga Building, from initially an abandoned building to finally becoming a building with the implementation of new functions(Andiyan \& Nurrisman, 2021).

\section{Basic Form}

Basic shape refers to the specific boundary of a plane figure or the surface configuration of a volumetric form. It is a major aid for us in recognizing, identifying and categorizing particular shapes and figures. Our perception of the basic structure will depend on the degree of visual contrast that exists along the contour separating a figure from its ground floor or between a shape and its area(Tawayha, 2019).

In architecture, we pay more attention to basic forms in the form of:

1. The floor, wall, and ceiling areas cover the space.

2. Openings - openings of doors and windows in spatial proximity.

3. Silhouette and contour of a building.

We know basic regular shapes from geometry, namely circles and an infinite series of regular polygons that can be inserted into them. Of these, the most important ones are the main basic ones: circle, triangle and square.

1. Circle

(Fracis D K Ching, 2008) The circle has a centre orientation, in the form of an introvert figure and is usually stable and centred. For example, placing a ring on a plane will clarify the space pust.

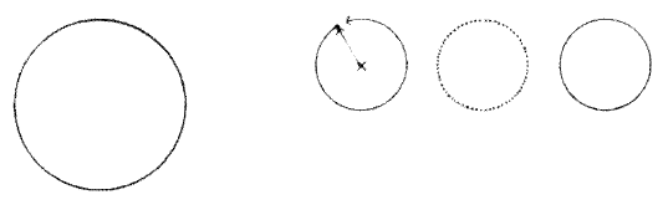

Figure 1 Circle Shape

(Source :(Fracis D K Ching, 2008))

\section{Triangles}

(Fracis D K Ching, 2008) said the triangle shows stability. Relying on each side, the triangle is a very stable figure. When standing on one side, the triangle can either become balanced in an equilibrium situation or become unstable and fall on the other side. 

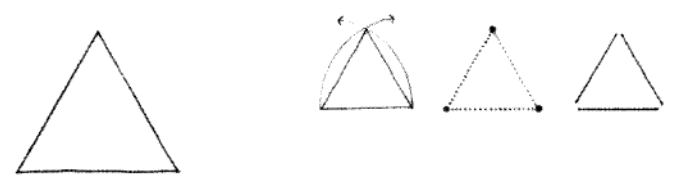

Figure 2 Triangle Shape

(Source :(Fracis D K Ching, 2008))

3. Square

(Fracis D K Ching, 2008) said the square symbolizes purity and rationality. This shape is symmetrical because it has two similar cut lines. All cube shapes are variations of the court, adding the width or height. Like in a square triangle, it will be stable when standing on one side and sweetened when standing on one end. When a square's diagonal is a vertical and a horizontal line, the court is in equilibrium.
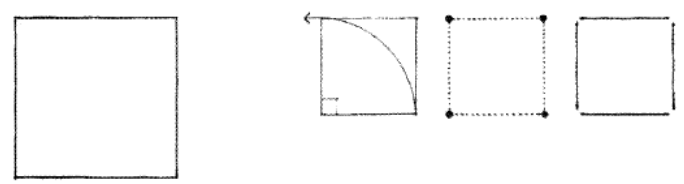

Figure 3 Square Shape

(Source :(Fracis D K Ching, 2008))

\section{Principles of Design}

1. Unity

The principle of unity concerning visual composition in design. Visual elements represent composition in this sense. Bricks, wooden blocks or concrete, which are commonly used as building materials to withstand the effects of weather or to support building structures, also create visual elements that can form compositions (Smithies K.W., 1982).

Composition without diversity can lead to monotony and boredom; diversity without rules creates chaos. The principle of unity is a visual tool that allows the various forms and spaces of a building to exist together in concept and perception in one unified whole (Fracis D K Ching, 2008).

\section{Proportion}

Proportion is the geometric relationship of the sides of a rectangle and its contents and the ratio or comparison of the different parts of a composition (Smithies K.W., 1982). Proportion serves to determine the position of the object against its surroundings or to the thing itself.

\section{Balance}

The main principle in all kinds of compositions is balance. Balance is a real quality of any object where the visual attention of the two parts on the two sides of the balance centre (centre of attention) is the same.

The aesthetic comfort produced by balance seems to have something to do with the quality of eye movement as moving from one ski to the other finds the same traction on the left half and right half, like a swinging bell pendulum, then finally comes to a satisfying stop on the right half. 
The midpoint between the two extreme ends produces a spontaneous feeling of comfort and energy(Rahmahesa, 2020).

The balance will show the sense of weight or weight produced by an object seen by the eye; visually, the importance of an object is determined by what the eye sees. Visually the thing is generated. For example, natural stone or a large number of bricks will appear heavy and overwhelm all attention. Thus the visual weight will affect the balance of the composition. In addition, the design will also be influenced by light and colour. The high mobility of the population and the movement of goods and services to and from Bandung by air can cause transportation problems.

4. Rhythm

Rhythm is defined as the regular or harmonious repetition of lines, shapes, forms or colours. In the principle of rhythm, when staring at a design, the eye moves according to the rhythm from one object to another (Fracis D K Ching, 2008).

\section{Center of gravity}

The emphasis of an important or striking thing from a form or space according to its size, cut, or placement relative to other states and areas of an organization (Fracis D K Ching, 2008). Good design has an eye-catching emphasis, achieved through repetition of size, contrast, arrangement and the unexpected.

\section{Scale}

Scale is a fun measuring system (measuring tool). It can be in $\mathrm{cm}$, an inch, or whatever of the units to be measured. The scale drawing is the dimension used for the drawing as a comparison. For example, a $1 \mathrm{~m}$ structure is drawn $1 \mathrm{~cm}$ in the picture. So the size in the image represents the actual size of the building. In architecture, what is meant by scale is a harmonious relationship between a structure and its components and humans. Everything we see is always compared to the size of the human din. This is done instinctively and usually goes unnoticed. Often people wake up after seeing something again. For example, a building that was last seen in childhood after being looked back at some time later feels like the building is not as large as imagined as it was seen in childhood. Humans are already accustomed to buildings that are larger than themselves, but this assessment is relative. Buildings made with very large sizes, for example, palaces, churches. That would be very impressive. The appearance of the building seemed to represent something greater or more important than humans. The harmonization of the room that blends with the outdoor space is one of the main points in contemporary architectural concepts (Wulandari, 2019).

The elements of scale is realistic aspects of a physical structure or other objects being designed: the line, shape, colour, texture, pattern, light, and so on. Meanwhile, on the other hand, the principles of scale describe the possible relationships through manipulation or expression of these elements, including rhythm, repetition, symmetry, balance, proportion, dominance, subordination, tension, diversity, and unity. The features and principles of the scale can form a certain composition that produces leaves that are either intimate, humane, monumental/grand or surprise.

\section{Sort - sequence}


According to H.K. Ishar (1992:110-121), units are a transition or change of experience in observing composition. The good sequences of these transitions or transitions flow smoothly, without surprises, without sudden changes. The purpose of applying the sequence principle as in architecture is to guide the visitor to the intended place and prepare for the climax. The sequence of experiences includes approach, progression and ending. In preparation, we can make framing, cursory views or transitions so that what will be seen is not surprising and warning. In the main experience, the visitor feels what he saw or experienced after entering. In the end, the visitor stops or takes a break. In the end, orientation guidelines or climax are required. This paper aims to explore the application of Society 5.0 on the intelligent society component in Bandung Smart City as an accelerator of solutions for fair use of technology in education and health(Kurniawan \& Andiyan, 2021).

Sequences have a beginning, direction and climax. The start is usually located at the beginning of the axis. The starting in an architectural composition can be in the form of an entrance or a transitional ruing such as a lobby. Direction is not necessary. The direction can be in the form of past people, elements on the sides of the axis, or it can be in the form of intermediate spaces. Direction is a guide to the end. To accentuate the dramatic ending, these directions are often shortened or omitted to enlarge the element of expected surprise. The rhythmic direction element makes people move subconsciously, looking for the end. If the direction flows from small to large, then this creates an even bigger climax. The climax is usually located on the axis. Here, the end of the axis is the surprise, or the most important centre of the experience, the main goal. The strength of the climax depends on the distance, rhythm, shape, and power of the direction(Katam \& Bhattacharyya, 2018).

\section{Research methods}

(Sugiyono, 2005, 2012) The method used by the author in this study is to use a qualitative approach with a descriptive system. This research is used to determine the geometric shapes and basic shapes of the Jardin Cihampelas apartment building through data collection, analysis, then interpreted in the analysis section(Sugiyono, 2012).

The techniques used in collecting data used in this study are:

\section{Observation Technique}

The observation technique used in this research is to directly observe how the shape of the building mass at the Jardin Cihampelas Apartment is to obtain data and facts in the field.

2. Study literature

Studying literature books, journals, and the internet related to the author's title takes as a comparison or basis for further discussion and to obtain the theoretical foundations of the system to be developed, so that report writing does not deviate from previous theories and acknowledges the truth.

Data analysis is carried out in a process, namely compiling, categorizing data, looking for themes to get their meaning. Analyzing qualitative data can be done according to (Nasution, 1996) namely:

A. Data Reduction

Data reduction is an analysis process carried out to sharpen, classify, and direct the 20 |Volume 5 Nomor 1 Agustus 2021 
research results by focusing on things that are considered important by the researcher.

B. Data Display / Data Presentation

Display data is a set of structured information that will provide a comprehensive overview of the research, in other words, presenting detailed and comprehensive data by looking for patterns and their relationships.

C. Data Conclusion

Data analysis has a very important position in conducting a study. Data analysis is carried out in a process, since data collection and after leaving the research field. This research is expected to be a reference for his research and can be developed again to a wider scale.(Andiyan \& Nurrisman, 2021)

\section{Results and Discussion}

The basic shape of the building mass is a rectangle connected to other rectangles, and each mass building block is designed with a typical shape. It consists of 4 building towers, namely towers $A, B$, $C$, and D. Each tower has 23 floors and a U shape; Towers A - B and C - D are located close to each other on the inside of the "U" shaped mass. (1) Land area: $\pm 8000 \mathrm{~m} 2$. (2) Total building area: \pm $106,247.71 \mathrm{~m} 2$. (3) Total area It. bottom: $\pm 4,000 \mathrm{~m} 2$.

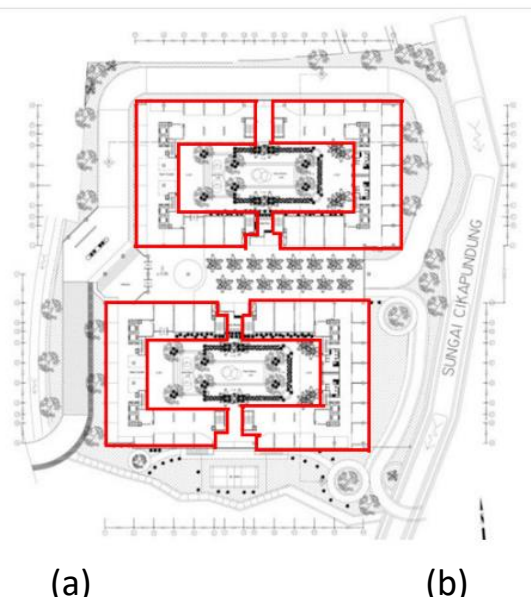

Figure 3 (a) The Jardin's site plan and (b) Mass Composition

(Source : (Utami, M. N., Ibrahim, M., \& Aziz, 2016)

1. Unity

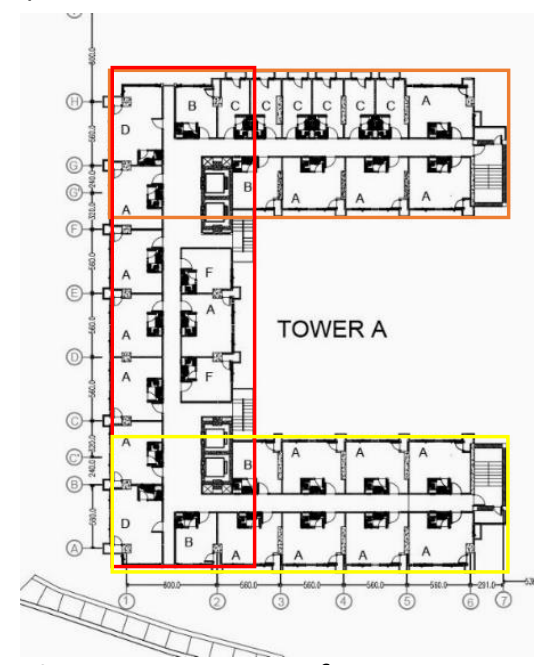

Figure 4 Location of unit $A 1129$

(Source : (Utami, M. N., Ibrahim, M., \& Aziz, 2016) 
Jardin apartment Cihampelas wear a basic form of three rectangles that are interconnected with one another create the building mass formations like the letter U(Absori, 2019).

2. Proportion

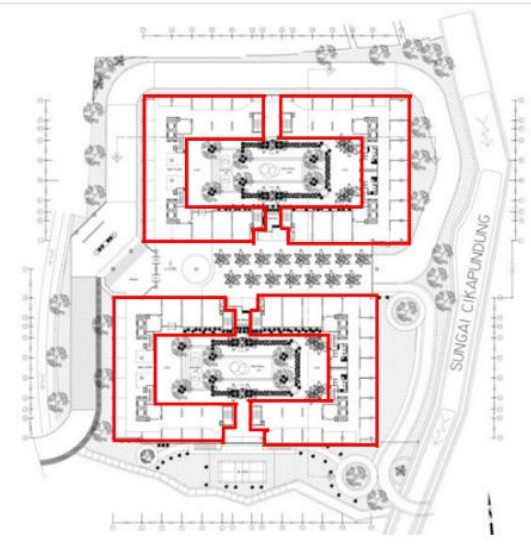

Figure 5 Siteplan of The Jardin

(Source : (Utami, M. N., Ibrahim, M., \& Aziz, 2016)

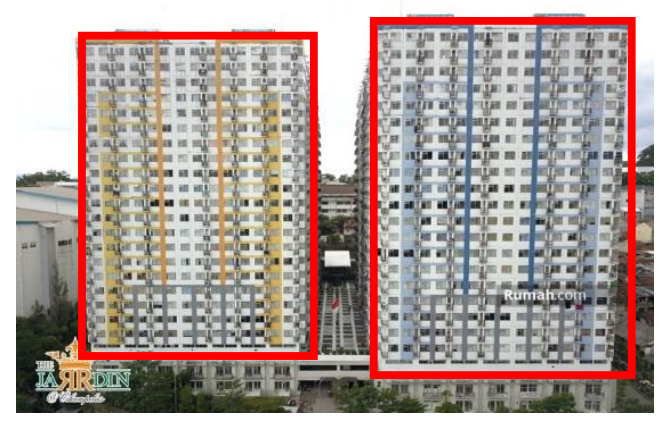

Figure 6 Front View of The Jardin

(Source: https://www.rumah.com/listing-properti/dijual-the-jarrdin-cihampelas-oleh-aryaputra-16089181)

The Jardin Cihampelas Apartment only has 1 Tower module; in other words, the shape of the apartment mass composition can be called the proportion in terms of the mass shape from above and from the side, each tower is the same size, seen from the front it also has a similar length and height.

3. Keseimbangan

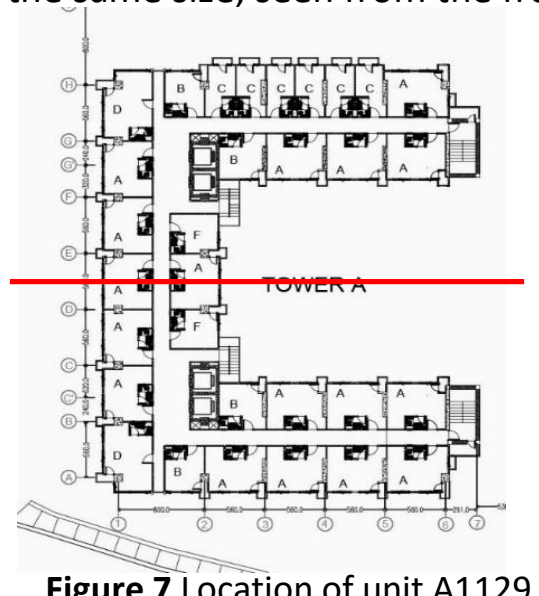

Figure 7 Location of unit A1129

(Sumber : (Utami, M. N., Ibrahim, M., \& Aziz, 2016) 
The drawing of a line in the centre of the Tower A plan shows the balance in the mass form of the Jardin Cihampelas Apartment building, which has similarities between the mass of the building when divided into two parts.

4. Center of gravity

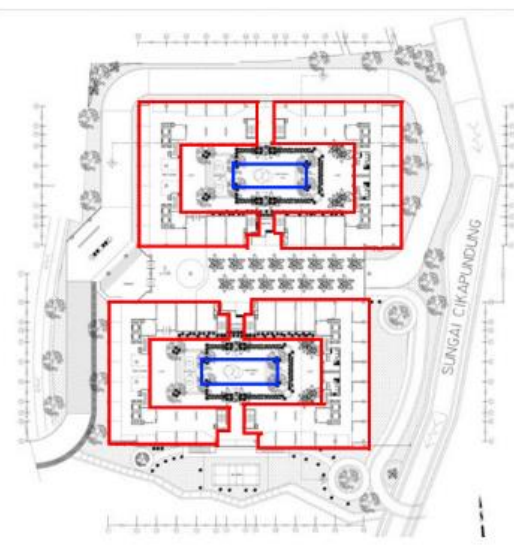

Figure 8 Siteplan of The Jardin

(Source : (Utami, M. N., Ibrahim, M., \& Aziz, 2016)

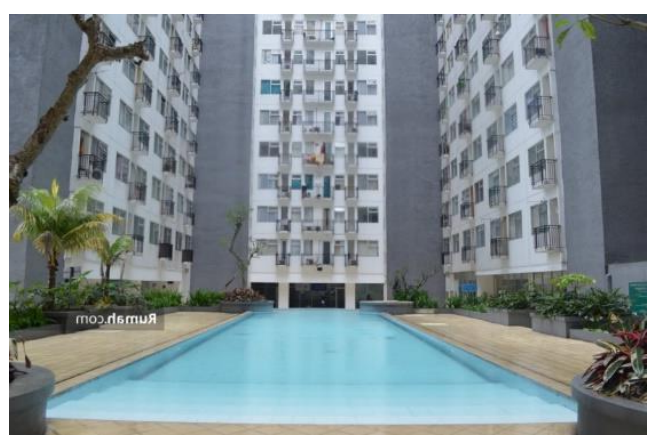

Figure 9 Swimming Pool The Jardin

(Source: https://www.rumah.com/listing-properti/dijual-the-jarrdin-cihampelas-oleh-aryaputra-16089181)

The Jardin Cihampelas Apartment focuses on the swimming pool surrounded by Tower A - B and Tower C $D$ respectively and the swimming pool with more open land.

5. Rhythm

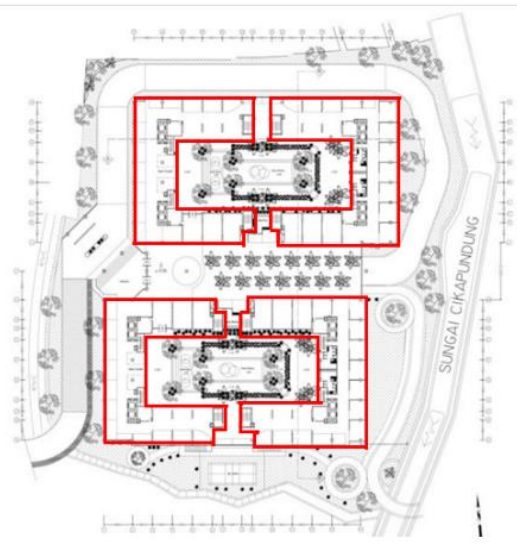

Figure 10 Siteplan of The Jardin

(Source : (Utami, M. N., Ibrahim, M., \& Aziz, 2016) 
Repetition of the shape of the building mass in one of the towers multiplied into four identical towers.

\section{Conclusion}

Based on the results of the analysis of the basic shape and geometry of the mass composition of the Jardin Cihampelas Apartment building, the authors conclude:

1. The basic shape of the mass building composition of the Jardin Cihampelas Apartment uses a basic rectangular shape that is arranged connected to other rectangles that apply the basic form of geometry.

2. Design principle elements such as unity, proportion, balance, emphasis, and rhythm in the composition of the building mass of the Jardin Cihampelas Apartment apply the points that experts on basic shapes and geometry have stated.

\section{Bibliography}

Absori. (2019). The sustainable development licensing policy of creative industry in the era of asean economic community (AEC) in Surakarta, Indonesia. Humanities and Social Sciences Reviews, 7(3), 25-31. https://doi.org/10.18510/hssr.2019.734

Andiyan, Rachmat, Agus. (2021). Analisis Manfaat Pembangunan Infrastruktur Kereta Api Di Pulau Jawa. Jurnal Pendidikan Dan Teknologi Indonesia, 1(3), 121-129.

Andiyan, Andiyan, \& Nurjaman, Andri. (2021). Pendekatan Urban Green Building Pada Bangunan Apartemen. RADIAL : Jurnal Peradaban Sains, Rekayasa Dan Teknologi, 9(1), 39-52.

Andiyan, Andiyan, \& Nurrisman, Okki. (2021). Implementation of the New Function of the Sarinah Braga Building (Hotel De Braga By Artotel). Solid State Technology, 64(2), 5689-5695. Retrieved from http://solidstatetechnology.us/index.php/JSST/article/view/10569

Cardellicchio, L. (2018). On conservation issues of contemporary architecture: The technical design development and the ageing process of the Jubilee Church in Rome by Richard Meier. Frontiers of Architectural Research, 7(2), 107-121. https://doi.org/10.1016/j.foar.2018.03.005

Ernst, Neurfert. (2002). Data Arsitek jilid 2. In Erlangga (Vol. 4). Retrieved from http://marefateadyan.nashriyat.ir/node/150

Fokaides, Paris A., Apanaviciene, Rasa, Černeckiene, Jurgita, Jurelionis, Andrius, Klumbyte, Egle, Kriauciunaite-Neklejonoviene, Vilma, Pupeikis, Darius, Rekus, Donatas, Sadauskiene, Jolanta, \& Seduikyte, Lina. (2020). Research challenges and advancements in the field of sustainable energy technologies in the built environment. Sustainability, 12(20), 8417.

Fracis D K Ching. (2008). Bentuk, Ruang Dan Tatanan. Bandung: Erlangga.

Hashimah, Wan, \& Ismail, Wan. (2015). Contemporary Uses of Buildings on a Heritage Street. Procedia - Social and Behavioral Sciences, 170, 633-641. https://doi.org/10.1016/j.sbspro.2015.01.065

Katam, Keerthi, \& Bhattacharyya, Debraj. (2018). Comparative study on treatment of kitchen wastewater using a mixed microalgal culture and an aerobic bacterial culture: kinetic 
evaluation and FAME analysis. Environmental Science and Pollution Research, 25(21), 2073220742.

Kurniawan, Mohamad Aghust, \& Andiyan, Andiyan. (2021). Disrupsi Teknologi Pada Konsep Smart City: Analisa Smart Society Dengan Konstruksi Konsep Society 5.0. Jurnal Arsitektur Archicentre, 4(2), 103-110.

Nasution. (1996). S. Nasution (1996:129-130). jakarta: Sinar Grafika.

Putri, Anggraeni Utami. (2015). Analisis Perbandingan Zoning Dan Siklus Bekisting Table Form System Pada Proyek Pembangunan Prima Orchard Apartement. Universitas Mercu Buana.

Rahmahesa, Reza Risnaldi. (2020). Kontekstualitas perancangan Hotel de Braga terhadap bangunan cagar budaya Sarinah.

Smithies K.W. (1982). Prinsip-prinsip Perancangan dalam Arsitektur. Bandung: Intermatra.

Sugiyono. (2005). Memahami Penelitian Kualitatif. Bandung: CV. Alfabeta.

Sugiyono. (2012). Metode Penelitian Kuantitatif Kualitatif dan R\&B. Bandung: CV. Alfabeta.

Tawayha, F. Al. (2019). Contribution of the vernacular architecture to the sustainability: A comparative study between the contemporary areas and the old quarter of a Mediterranean city. Sustainability (Switzerland), 11(3). https://doi.org/10.3390/su11030896

Utami, M. N., Ibrahim, M., \& Aziz, N. (2016). Penghawaan Alami Pada Unit dan Koridor Rusunami The Jarrdin. Reka Karsa. Bandung: Reka Karsa.

Wulandari, Risti. (2019). Perancangan Bandung Hotel Dan Resort, Pada Lahan Kontur Jl. Terusan Sersan Bajuri, Desa Cihideung, Kelurahan Isola Kecamatan Sukasari, Kota Bandung Jawa Barat (SITE C). Universitas Mercu Buana Jakarta. 
Study Of Building Mass Forms In Jardin Cihampelas Apartment 